\title{
Arms industry data: Knowns and unknowns
}

\section{Keith Hartley}

Keith Hartley is Emeritus Professor of Economics, University of York, York, United Kingdom. He may be reached at kh2@york.ac.uk.

\section{Abstract}

This article surveys the past, present, and possible future nature and features of the global defense, arms, and security industry and associated data collection issues. It concludes with remarks on the economics of data, the public goods nature of data, and the incentive-reward system in the data market.

$\mathrm{T}$ he focus on knowns and unknowns can be expressed in three questions. First, what is known; second, what is not known; and third, what do we need to know for a better understanding of arms industries? The short answer to all three questions is quite a lot. There is a lot which we know; a lot which we do not know; and a lot which we need to know. The approach to these questions involves consideration of the defense economics problem reflected in rising costs and the economics of arms markets. Arms industries need to be defined and data requirements in an ideal world are reviewed. The future of the defense firm is assessed and the conclusion deals with "where next?" for data requirements.

The defense economics problem

The defense economics problem takes the form of rising unit equipment costs in real terms leading to intergenerational cost escalation. In the United Kingdom, examples of annual real unit cost escalation over the period 1955 to 2010 has ranged from some 2 percent for frigates, to 6 percent for aircraft carriers and tanks to 7 percent for combat aircraft. More examples of rising unit costs are shown in Table 1. Here, unit airframe costs in real terms doubled or more than doubled between generations of aircraft. ${ }^{1}$

Rising unit costs of equipment affect the arms industry and armed forces. For industry, there are fewer new types of equipment and smaller production runs for each type. For example, in the mid-1950s, the U.K.'s Royal Air Force (RAF) operated about 1,000 fighter aircraft but by 2018, the numbers had declined to 160 Typhoon aircraft. Rising costs for both development and production means that some nations can no longer afford to buy modern combat aircraft. For example, New Zealand has abandoned a fighter aircraft capability for its air force.

Rising costs provide greater incentives for nations to import arms, especially from the United States, but will also lead to increased role specialization in military alliances even as the extent of such specialization will be limited by the acceptance of trust between alliance members (e.g., in a conflict, will other members "turn-up"?). In addition, rising costs will provide greater incentives for defense policymakers to substitute among cost, time, and performance in weapons acquisition. For example, there might be a greater willingness to sacrifice ambitious performance targets to achieve cost and delivery targets. And, governments will always promise acquisition reforms to control cost growth (although usually such reforms will fail and represent a triumph of hope over experience).

The economics of arms markets

Arms markets comprise buyers and sellers, where governments

Table 1: Rising unit costs

$\begin{array}{lc}\text { Aircraft type } & \begin{array}{c}\text { Airframe unit costs } \\ \text { (fs, 2017 prices) }\end{array} \\ \text { Gladiator (1937) } & 142,629 \\ \text { Spitfire (1939) } & 230,969 \\ \text { Meteor (1945) } & 507,150 \\ \text { Hunter (1955) } & 1,224,000 \\ \text { Lightning (1960) } & 4,345,000 \\ \text { Typhoon (2003) } & 34,208,000\end{array}$

Notes: (1) Costs are for airframes only comprising fuselage, wings, and tail but excluding engines, guns, undercarriage, radio, and avionics. (2) Dates refer to date of contract. Gladiator was a biplane; Spitfire was a monoplane; Meteor was a first generation jet fighter. Between the Lightning and Typhoon, the U.S. Phantom and U.K. Tornado fighter were in service but no cost data were available, hence the massive rise in unit costs between the Lightning and Typhoon which reflect missing observations for these generations of aircraft. (3) Unit costs for bomber/strike aircraft are not shown in this Table. 
are buyers and arms firms and industries are suppliers. Governments dominate these markets. Governments are major buyers or the only buyer (monopsony buyer). Government can use its buying power to determine the arms industry's size, ownership, structure, entry and exit conditions, conduct, and performance. Often, the supply side or arms industry is characterized by domestic monopoly, duopoly, or oligopoly, especially for high technology weapons (e.g., combat aircraft, helicopters, missiles, nuclear submarines). There are both entry and exit barriers and firms are either privately-owned or state-owned. Privately-owned firms are subject to different incentives, motivated by profitability, rivalry, and "policing" by capital markets reflected in "hard" budget constraints. In contrast, state-owned arms-makers might be protected from competition, are not exposed to the pressures of private capital markets, and operate with "soft" budget constraints.

While rising costs and arms markets are major issues, others are important as well, and examples include industry structure, with its typical prime contractor and complex supply chains, and the constant drive for new technologies leading to new types of military strategies and new kinds of warfare. Compared with civilian markets, where technical change is often associated with falling prices, such changes in military markets lead to higher quality and costlier equipment (i.e., more advanced rather than cheaper equipment).

\section{Questions on arms industries}

Why are we interested in arms industries and what are the key data questions? Arms industries use scarce resources with alternative uses. As a result, we need to know the size of these industries which forms a major data requirement. We also need to know the alternative uses of arms industry resources. How transferable are its resources, which forms another data requirement. The conversion question also needs to be addressed, in both directions. In disarmament, how quickly and easily are resources transferable from military to civilian uses and in rearmament, how quickly can arms industries be reconstituted? Identifying the questions is easier than obtaining answers. For example, difficulties arise in identifying and measuring resource transferability and the speed of the adjustment process. At a more basic level, governments frequently introduce defense industrial policies without data and information on the size and structure of their national defense industrial base.

\section{Definitions}

Arms industries have been the subject of various definitions, and international comparisons need to be based on some common definition. A starting point defines arms industry as
This article surveys the past, present, and possible future nature and features of the global defense, arms, and security industry and associated data collection issues. It concludes with remarks on the economics of data, the public goods nature of data, and the incentive-reward system in the data market.

all firms involved in the design, development, production, and sale of arms where these are defined as lethal equipment. But such a simple definition is not without its problems.

Debates about arms industries often focus solely on their major prime contractors (e.g., the SIPRI top-100 arms producers). This is misleading since there is an extensive supply chain providing inputs for the prime contractors. For example, military aerospace prime contractors purchase major inputs from firms supplying avionics, engines, landing gear, and materials for constructing aircraft. In turn, each major supplier has a supply chain of firms providing inputs for avionics, engines, landing gear, and so on. As a result, supply chains are complex; they differ between air, land, and sea systems; they might be international; and published data are generally not available on defense industry supply chains. The presence and complexity of supply chains raises further definitional problems in identifying the limits of arms industries. At which level in the supply chain do we determine the extent of arms industries (e.g., levels three, four, etc?). In some cases, firms might not be aware that they are involved in supplying to arms firms. For example, firms supplying ball bearings and track might not be aware that these products might be inputs for tanks. But collecting data on arms industry supply chains is time-consuming and costly.

There are further problems in defining arms industries. Should the definition include nonlethal equipment? Defense ministries usually make substantial purchases of nonlethal goods and services. Examples include construction and accommodation, computers, vehicles, and services such as accountancy and financial advice, training and transport. In some nations, defense ministries are making greater use of military outsourcing than in others.

The definition used as a starting point excludes post-production activities. These include repair, maintenance, modifications, up-dates, and disposal. Increasingly, with financial pressures on defense budgets, some of these activities are being outsourced to private contractors (e.g., maintenance, training). As a result, private firms are replacing activities traditionally undertaken "in-house" by the armed forces. Disposal forms another industrial sector ranging from simple to complex and costly activities. The simple end of the disposal industry embraces the sale of surplus military equipment, or its 
destruction and sale as scrap metal. The more complex end involves the disposal of nuclear systems (e.g., nuclear bombs, submarines, etc) and the decontamination of nuclear sites which can be exceedingly costly.

Technical progress also affects the definition of arms industries. Technical change can lead to the new entry of firms and the creation of new industries. For example, the aircraft industry did not exist in 1900, nor did firms such as BAE Systems, Boeing, and Lockheed Martin. Similarly, missiles, space systems, and the nuclear weapons industry developed after the second world war created new markets, new firms, and new industries.

\section{Data requirements in an ideal world}

Ideally, full and complete understanding of arms industries requires data on their size, structure, conduct, performance, and ownership. All of these variables are influenced by national governments, and a corresponding data collection approach is based on the structure-conduct-performance model in industrial economics, a standard economic method of analyzing any industry.

\section{Industry size}

Industry size can be measured by sales and employment. Again, problems arise where international comparisons use different definitions of arms industries. For example, some employment data are based on direct employment only while others include indirect employment among suppliers even as the latter might be based on different definitions of supply chains. Furthermore, supply chains are complex and differ between air, land, sea, and nuclear systems. Moreover, published data are generally unavailable on arms industry supply chains.

There are different data sources on industry size. Often, governments fail to provide and publish official statistics on their national defense industry. In some cases, the official statistics are limited to a few clearly-defined defense industry groups such as the annual sales of weapons, ammunition, and fighting vehicles. Data on other defense-dependent industry groups such as aerospace and shipbuilding include civil as well as military sales.

Some industry trade associations also provide sales and employment data for their industry (e.g., aerospace, electronics, shipbuilding). But trade associations use various definitions of an industry and their employment data might include all sources of employment, including induced employment reflecting jobs created by the spending of defense industry workers (e.g., in local shops and restaurants). Industry trade associations might also be aiming to maximize the size of their industry by maximizing its sales and employment numbers.

\section{Industry structure}

Industry structure focuses on the number of arms firms in the industry and their size (both absolute and relative size). Industries might be competitive, comprising large numbers of relatively small firms, or monopolistic, comprising a single seller of a product or service. Or they might be oligopolistic, comprising a small number of relatively large firms. Each industry structure has different efficiency outcomes, ranging from a socially desirable competitive outcome to a socially undesirable monopoly with arms industries revealing examples of each type of structure.

Governments determine arms industry structure through procurement policy and contract awards, through preferential purchasing (e.g., buy U.S. or buy French), through allowing or banning mergers, and by allowing or preventing foreign competition for national arms contracts. For example, between 1958 and 1960, the U.K. government used its powers over contract awards to restructure the aircraft industry and reducing it from a large number of aircraft and engine firms to five major groups. ${ }^{2}$

Structure embraces entry and exit conditions for the arms industry which are also determined by national governments. For example, governments support their "national champions" by protecting them from rivalry, especially from foreign competition. Or, government can prevent exit by "bailing-out" arms firms where intervention might involve the state-ownership of a private firm, subsidy payments, or a generous contract award (e.g., a new cost-plus arms contract).

The arms industry structure has some distinctive features. Arms industries are decreasing-cost industries reflecting economies of scale and learning. Typically, arms firms are large firms forming national monopolies, duopolies, and oligopolies with examples of each structure in each sector of air, land, and sea systems for each nation. For example, for combat aircraft, European nations are characterized by national monopolies compared with a national oligopoly in the U.S. Similarly, for nuclear submarines, there are monopoly suppliers in each of France and the U.K. compared with a domestic duopoly in the United States. U.S. firms dominate the arms industry, especially for aerospace equipment (aircraft, helicopters, missiles, space systems). ${ }^{3}$

Arms industry ownership reflects a mix of private and state ownership. Private ownership is typical in the U.S., the U.K., Germany, and Sweden whereas state ownership is prevalent in China, Greece, India, Italy, Russia, and Spain.

The arms industry has not been static. There has been 
considerable industrial restructuring reflecting changes in the demand for arms and technical progress. For example, the rearmament prior to the second world war resulted in new entrants and larger firms while the end of the cold war-era led to mergers and exits from the industry. Technical progress has also led to new entrants. The emergence and development of the aircraft and aerospace industry over the period 1900 to 2018 created a new industry which eventually developed into the aerospace industry embracing helicopters, missiles, unmanned aerial vehicles (UAVs), and space systems.

\section{Industry conduct}

Conduct is about the form of competition used in the arms industry. Competition ranges between price and nonprice competition. Nonprice competition is varied and embraces advertising and marketing, R\&D policy, offsets for arms exports, national procurement policy, and lobbying for arms contracts where there are opportunities for bribery and corruption. Of course, bribery and corruption are not confined to the arms business and occur in other industries (e.g., public procurement and sports such as athletics, cricket, cycling, football, and tennis).

Arms markets embracing both buyers and sellers are subject to change with new markets emerging. Examples include new markets for UAVs, cyber systems, and for military outsourcing (e.g., private firms providing military training and managing military facilities such as firing ranges and accommodation).

Differences in pricing arise between military and civilian markets with implications for the transferability of resources between these markets. Prices in arms markets might be cost-based or cost-plus where firms recover all their costs regardless of cost levels and are guaranteed a certain level of profits. In contrast, prices in civilian markets are demand-sensitive responding to market pressures where firms might incur losses. The entrepreneurship required in civil markets creates an entry barrier for arms firms seeking to transfer resources from military to civil markets. Also, arms firms' resources might not be easily and quickly transferred from military to civilian uses: Resource transfer can be costly.

\section{Industry performance}

Various indicators can be used to measure the performance of arms firms and industries. Possibilities include prices, profits, productivity, and exports. Other indicators include the progress of projects against contract schedules reflected in cost overruns and schedule slippages. Further performance indicators embrace comparisons of arms industries with other civil industries such as motor cars, computers, and pharmaceuticals.
These comparisons allow an assessment of the alternative use value of resources used in arms industries: What are the alternative uses of resources?

While there is no shortage of performance indicators, there is the perennial problem of finding actual published data. In some cases, data can be obtained from project case studies. For example, some governments publish data which allows comparisons between costs, prices, time-scales, delays, and exports for similar major arms projects. Such data can be obtained for the U.S. F-35, European Typhoon, French Rafale, and Swedish Gripen combat aircraft.

The challenge of comparing arms industries with civil industries requires the choice of an appropriate civil industry comparator which publishes similar data. Productivity comparisons are an obvious performance indicator derived from data on sales and employment. But productivity figures require further choices between labor or value-added productivity. Value-added productivity is preferred since it based on a firm's value-added rather than its gross sales or turnover which includes purchases of inputs from suppliers.

In measuring and assessing performance, further distinctions can be made between firms and industries. Industries comprise groups of firms producing similar products while firms are the basic component of an industry. Typically, official government statistics identify industries and present industry performance data. In contrast, firm-level performance data are obtained from a company's annual report or accounts which vary between firms and nations.

\section{Exceptions}

There are some major exceptions to the traditional view of arms markets which often views arms industries as dominated by a small number of large firms. The media and anti-arms groups like to focus on the behavior of a few large arms firms (e.g., BAE, Lockheed Martin) where the interest is on their profitability and performance on major arms contracts. In fact, numerically, arms industries are dominated by small firms: They comprise large numbers of small firms as represented in supply chains. There are also examples where small firms are the appropriate economic size for the production of some arms. An obvious example is small arms which are usually produced by small firms.

Further exceptions to the traditional view arise in those cases where arms are produced by terror groups. For example, the 9/11 attacks in the U.S. were an example of a terrorist group creating a private air force using airliners as "flying bombs". Other examples arise where terror groups convert civil vehicles and trucks into armored fighting vehicles and rubber dinghies into fast patrol boats. The ultimate example is where 
suicide bombers become the equivalent of precision guided weapons.

Private arms markets provide a role for arms dealers. These agents facilitate trade in arms by bringing together buyers and sellers and arranging market transactions. Some of these markets and transactions might be illegal (illegal arms markets) with further opportunities for bribery and corruption. Also, mercenary forces might be among the buyers in private arms markets. Typically, mercenary forces are buyers of small arms (ammunition, rifles, light artillery). They might also buy used helicopters, and they will improvise to create armored fighting vehicles and vehicle transport.

\section{Market failures}

Market failure analysis allows an assessment of how well arms markets are working. Usually, left to themselves private markets fail to work properly in the sense of failing to fully and accurately respond to consumer preferences. Market failures arise from imperfections on both the buying and selling side of markets (e.g., monopolies, entry barriers) and from beneficial and harmful externalities (e.g., defense and peace as public goods, pollution). In principle, state intervention can be used to correct for failures and aim to improve the operation of markets. However, identifying market failures is only the start of the analysis. The causes of market failure have to be identified, the costs of any proffered corrections have to be estimated, and choices made between various policy solutions (e.g., tax/subsidy policy, various forms of regulation, state ownership).

A competitive market with large numbers of buyers and sellers together with free entry and exit is used as the ideal-type model for assessing market failure. Failures on the demand side of arms markets arise from government. Government is a dominant or single buyer. It controls information on demand requirements, and it controls entry and exit. Consumers are unable to register accurately their demands and willingness to pay for defense (defense is a public good). Failures on the supply-side arise from monopoly, oligopoly, and entry barriers. There are, for example, high entry costs required for the costly $\mathrm{R} \& \mathrm{D}$ for modern high technology weapons (e.g., combat aircraft, missiles, space systems). There might also be barriers to exit with government funding major arms firms threatened with bankruptcy so that they remain in the industry. Overall, there is a presumption that arms markets are failing to work properly with opportunities for state intervention to improve their operation. However, care is needed since state intervention might have adverse and perverse effects (making the situation worse) and an overall assessment is needed to ensure that intervention is, on balance, worthwhile.
Alternatives exist to the traditional structure-conductperformance model. Markets can be analyzed as contestable or modified to allow for the Austrian School's view where markets are never at rest and never reach equilibrium. Instead, in a world of uncertainty, markets are constantly changing and in continuous disequilibrium. More fundamentally, the traditional approach has been modified by the introduction of game theory which recognizes the role of interdependence between small numbers of sellers and between a single government buyer and a few sellers. For example, in oligopolistic industries, the actions of small numbers of firms will be based on the expected reactions of their rivals (e.g., to price changes). Similarly, where there are few suppliers and competition is used to award large arms contracts, there is always the possibility that a losing firm will acquire the winner!

\section{The future of the arms firm}

Do arms or defense firms have a future and what might they look like in the year 2050? Predicting the future is hazardous and likely to be wrong. However, some general principles can be suggested.

Arms firms will survive so long as threats exist to nation states or are perceived to exist. But the future arms firm will be as different as today's arms firms are from those of 1945 or 1900. For example, BAE Systems did not exist in 1945. Nor did space travel exist in 1945. And, in 1900, aircraft and aircraft firms did not exist. There are likely to be new entrants as well as exits. In the future, electronics firms might emerge as prime contractors and traditional "metal bashers" such as tank firms might depart the arms industry.

The future arms firm might be larger and less dependent on government (e.g., through diversification into civil markets). Government will also have to review the profitability of defense business if arms firms are to be induced to remain in the business. This will require a review of the profitability of noncompetitive defense contracts. These raise efficiency and equity issues. Noncompetitive contracts for monopoly suppliers need to provide efficiency incentives acting as hard budget constraints, avoiding the inefficiencies associated with cost-plus contracts. At the same time, there are equity issues requiring a fair and appropriate reward for monopoly suppliers. ${ }^{4}$

The future will also be dominated by the continued rising unit costs of arms with impacts on the armed forces and arms industries. Rising costs have led to forecasts of a future comprising a single-tank army, a single-ship navy, and a single Starship Enterprise for the air force. For arms industries, there will be fewer but more complex types of new equipment with 
smaller production runs for each type.

There will be continued technical change requiring changes in both armed forces and arms industries - but both groups might resist change. Also, technical change can be evolutionary or revolutionary, with revolutionary change requiring greater adjustments by the armed forces and arms firms. The introduction of tanks, the jet engine, and atomic weapons were past examples of revolutionary technical change. The future will present further examples of revolutionary technical change but, currently, these are unknown and unknowable. Even so, arms firms will survive since they have a unique expertise, namely, their expertise in the weapons business.

Governments, arms firms, and arms industries face a further future challenge in the form of how to retain arms industry capacity during troughs in development and production work. Possible solutions are not costless and include technology demonstrators, mid-life updates, and mothballing. Cheap technology demonstrators enable arms firms to retain technologies and R\&D staff for next-generation equipment. Mid-life updates also provide work allowing arms firms to retain both $R \& D$ and production workers. Mothballing appears an attractive solution to retaining capacity, especially plant and equipment (e.g., jigs and tools for F-22 aircraft), an approach often used in civil industries (e.g., steel plants, coal mines). However, mothballing not only involves costs in policing and maintaining idle capacity but, more importantly, costs in retaining skilled labor. Retaining research scientists and technologists requires that they be offered challenging and meaningful tasks and similarly for skilled production workers. Without "real" work, skilled research and production staffs will quit for alternative employment.

Developments in the security industry provide a further challenge for arms industries. The security industry embracing internal or homeland security involving surveillance in public places (e.g., underground trains, water supplies), cyber security, and border control issues has led to an expansion of what was previously viewed as a more narrowly-drawn defense/arms industry. Although security companies do not produce lethal products, the business prospects in the security area has led arms firms to move into this area. These developments have occurred alongside the introduction of electronics/optics, information technology, and robotics, all of which might have dramatic effects on the future arms firms.

\section{Data requirements: the knowns}

Surprisingly, most governments do not provide basic data on their arms industries. Until recently, the U.K. was an exception with its Ministry of Defence (MoD) providing defense industry employment data distinguishing between direct and indirect employment and regional employment data dependent on U.K. defense spending and defense exports. However, in 2009, it decided to discontinue publishing such statistics, mainly because the "data did not directly support MoD policy-making and operations." "There were also concerns about the accuracy of some of the employment data and the mistaken impression that decisions about contracts were made on a regional basis.

Elsewhere, the U.K. official statistics only identify two specialist defense industries, namely, weapons and ammunition and fighting vehicles. Official U.K. statistics are available for other defense-dependent industries, including aerospace and shipbuilding, but these report total annual output comprising both military and civil output.

Industry trade associations are a further data source. For example, the U.K.'s Aerospace, Defence, Security and Space Association publishes annual data on total aerospace sales but again such totals comprise both military and civil sales. Similarly, the U.S.'s Aerospace Industry Association publishes good quality data with some defense data. Other data sources include annual company reports, but these differ in the quality of coverage and often present only total sales data comprising military and civil sales. BAE Systems is an exception. It is a defense-specialist firm providing sales and employment data for each of its various defense divisions. Some further sources of data emerge as by-products of other studies. For example, the 2017 U.K. Shipbuilding Strategy provided an overview of the U.K. warship industry identifying its major firms and new entrants. Similarly, data on project case studies provides useful information for analysis of comparative performance. For example, the U.K. and the U.S. regularly publish official data on the performance of major arms projects and their contractors, showing their total costs and cost overruns, delays, and performance failures. Examples include data on such projects as the Typhoon combat aircraft, the U.K. aircraft carriers, the collaborative A400M airlifter, and the US F-35 combat aircraft. ${ }^{6}$

Overall, on data availability, there are substantial knowns although considerable searching is required and in many cases, approximations have to be accepted with scope for imagination and ingenuity. National data might have to be constructed from industry trade association sources. For Europe, data are available from the European Commission, the European Defence Agency, and the Aerospace and Defence Industries Association of Europe. The Stockholm International Peace Research Institute provides data on large arms firms and some performance indicators are available (e.g., from project case studies). On industry structure, most arms firms are large firms in national monopoly industries with the exception of the U.S. 
where the typical structure ranges from duopoly to oligopoly for high technology weapons. Comparative firm and industry performance is more easily addressed since there are published data on a variety of civil firms and industries. But what of the unknowns?

\section{Conclusion: Where next?}

There is no shortage of future requirements for arms industry data. SIPRI's annual list of the top-100 arms producers has made an invaluable and original contribution to our knowledge and understanding of arms industries. But much remains to be done. The top-100 list could be expanded to, say, the world's top-150 arms firms. There are gaps to be addressed, namely, the need for accurate data on arms firms in China, North Korea, and Iran. Defense industry supply chains and small arms firms need to be recognized. ${ }^{7}$

The lack of data is related to the political nature of arms markets. Governments have influence on arms industries and on their size, structure, conduct, performance, and ownership. However, despite their influence, they are often reluctant to provide data on their national defense industrial base (e.g., on arms exports).

Compiling a list of data gaps is the easy part. Data additions can be costly and are not costless: Someone has to fund data searches. This raises a more general issue about the economics of data and the incentive-reward system in the data market. Published data are a public good where there is nonexcludability and nonrivalry in consumption. Nor do universities provide an appropriate incentive-reward system to scholars who specialize in data collection. Instead, the rewards for university scholarship are based on academic publications in top-rated journals where the focus is on highly abstract models and theories. As a result, the collection and widespread publication of data on arms industries is unlikely to be encouraged by universities. The public goods nature of data collection and publication on arms industries means that it is unlikely to be funded by private firms. Thus, data collection efforts require funding by state agencies or by charitable institutions (e.g., with a focus on peace research). ${ }^{8}$

\section{Notes}

The author thanks participants in the SIPRI Arms Production Project Workshop held 22-23 March 2018 at the Stockholm International Peace Research Institute, Stockholm, Sweden, and an anonymous referee for this journal.

1. Examples of cost escalation: See Davies, et al. (2011).

2. U.K. aircraft industry restructuring: Hartley (2017).

3. Decreasing-cost industry: Hartley (2017, chapter 3).
4. Review of noncompetitive defense contracts: Hartley (2019). 5. $\operatorname{MoD}(2009$, p. 21).

6. U.K. Shipbuilding Strategy: See MoD (2017).

7. SIPRI also has contributed valuable data on military expenditure. Together with its data on arms firms, it has helped researchers to gain a greater understanding of the military-industrial complex.

8. The author and Jean Belin (Bordeaux University) are preparing an edited volume which will address some of the data gaps and issues raised in this article. It will be titled The Economics of the Global Defence Industry and is to be published by Taylor and Francis as part of its Defence and Peace Economics Series (London, forthcoming 2019 or 2020).

\section{References}

Davies, N., et al. 2011. Intergenerational Equipment Cost Escalation. Report. London: Ministry of Defence.

Hartley, K. 2017. The Economics of Arms. Newcastle, UK: Agenda. https://doi.org/10.2307/j.ctv5cg7q6

Hartley, K. 2019. "The Profitability of Non-Competitive Defence Contracts: The UK Experience." Defence and Peace Economics (forthcoming).

[MoD] Ministry of Defence. 2009. UK Defence Statistics. Defence Analytical Services and Advice. http://webarchive.nationalarchives.gov.uk/201401161424 43/http:/www.dasa.mod.uk/publications/UK-defence-stat istics-compendium/2009/2009.pdf

[MoD] Ministry of Defence. 2017. National Shipbuilding Strategy. London: Ministry of Defence. (September). 